\title{
Legal Concept for Remote Sensing as the Foundation of Indonesian Space Law
}

\author{
Zunnuraeni Zunnuraeni \\ Faculty of Law \\ Universitas Mataram \\ Mataram, Indonesia \\ Minollah Minollah \\ Faculty of Law \\ Universitas Mataram \\ Mataram, Indonesia
}

\author{
Muhammad Ilwan \\ Faculty of Law \\ Universitas Mataram \\ Mataram, Indonesia \\ Erlies Septiana Nurbani* \\ Faculty of Law \\ Universitas Mataram \\ Mataram, Indonesia \\ erlisseptiana@unram.ac.id
}

\begin{abstract}
This research departs from the existence of a legal vacuum in the international law concerning remote sensing. Therefore, there are no legal instruments that can protect the sensed countries, particularly least-developing and developing countries. The purpose of this study is to develop a legal concept that can be used by Indonesia in national legislation of space law. This research is a doctrinal research with qualitative analysis. This research concludes that Indonesia shall develop its national law concerning remote sensing based on the legal concept of the Data Access for sensed countries with a special consideration for developing countries. This legal concept can be established into international customary law by holding international cooperation among least-developing and developing countries.
\end{abstract} law

Keywords - legal concept; remote sensing; Indonesian space

\section{INTRODUCTION}

Using Daniel Golston dan Ben Baseley-Walker's definition [1], Indonesia ${ }^{1}$ may be categorized as a middle power space state. This situation puts Indonesia-like other middle power spaces - in a susceptible position. National security and economy are the most vulnerable fields as the consequence of a space reliance on a foreign provider for space-based services.

The expensive cost of national security programs through space-based services forces many middle power states to use commercial space providers. Even though this can benefit the state since the financial burden may be shared with the commercial provider, it has an inherent risk. Among those risks are the limited-term in accessing the data and also the probability of the misuse of data for nefarious purposes by other actors [2]. This programme shall protect national security precisely endanger state's security.

Space reliance on the "middle space power" state to the foreign provider, either states or private companies, may also harm the state's economy. Nowadays satellites may be utilized to support economic activities. However, the lack of mastery of satellite technology may be misused from the interests of other parties. Developing countries have sounded economic extortion by space technology power. Indian

${ }^{1}$ Indonesia already have some satellite for varied purposes, among them are: Palapa satellite, BRIsat satellite, Merah Putih satellite, Nusantara Satu Sattelite. However, Indonesia still using some foreign satellite. Those foreign service satellite using for communication and broadcast transponder and weather monitoring. representatives echo the fears of developing countries concerning the use of space power, particularly the remote sensing activities, as a tool of economic exploitation [3].

Five major international conventions regarding outer space were made in the era of the Cold War. Those conventions include; Treaty on Principles Governing the Activities of States in the Exploration and Use of Outer Space, including the Moon and Other Celestial Bodies; Agreement on the Rescue of Astronauts, the Return of Astronauts and the Return of Objects Launched into Outer Space; Convention on International Liability for Damage Caused by Space Objects; Convention on Registration of Objects Launched into Outer Space; Agreement Governing the Activities of States on the Moon and Other Celestial Bodies.

After the end of the Cold War Era, various activities regarding outer space utilization develop rapidly. One of those activities is remote sensing using satellite. Principles of remote sensing made in 1986 containing twelve principles regulate these activities. However, these principles have not made the firm rules in respect to the protection of the sensed states from the sensing activities either by states or private companies. Moreover, the principles of Remote Sensing 1986 are not legal rules with a binding force. Therefore, the states do not have an obligation to fulfill those principles. Loh Ing Hoe et al. confirmed this by stating: "...clearly from the above literature review, the breach of principles listed under the Remote Sensing Principles 1986 will not entail any state responsibility because the nature of the soft law is a non-binding agreement" [4].

This legal vacuum in the outer space law regarding remote sensing activities may originate from domestic legislations. Yan Zhao argues that domestic legislation in the field of outer space is crucial to deal with the stagnation in outer space law. He contends that domestic legislation can be the answer for the legal vacuum that particularly originates from the growth of private companies' engagement and interest in outer space activities [5]. He further explains that domestic legislation development might be the beginning of outer space rules in respect of outer space exploitation. It also might be a transition era between the legal vacuum and the international rules [2]. 
This paper takes a small step in discussing the proper legal concept in remote sensing. The aim is to develop a legal concept that can be used by the middle space power country, particularly Indonesia, to embody national legislation and national policy that can protect their national interests.

\section{METHOD}

This research is doctrinal research. The data used is library data, which is derived from various journals and scientific articles as well as various legal rules. All collected legal materials are classified, categorized, analyzed and constructed as well as developed through analytical prescriptive elaboration.

\section{RESULT AND DISCUSSION}

\section{A. Legal Concept for Remote Sensing Activities}

There are numerous non-binding principles that might be developed to be the legal concept to build a national space law. This part will discuss some of those non-binding principles, particularly the legal concept for remote sensing activities. Those principles including the general concept come from the special needs and interests of the developing countries to the particular concept for the benefit of the sensing and the sensed states concerning the sensing activities.

\section{B. Needs and Interest of the Developing Countries}

This legal concept is a general concept that is already developed and accepted in international legal system, particularly post World War II. The entry of newly independent countries, especially Asia-Africa, gave a new color to the international legal system that was previously dominated by European countries. The difference between "the Old States" and "the New States." The consequence of that difference is described by R.P Anand as follows:

"The active participation of Asian and African countries in international relations has broken open the exclusive club of Western Christian Powers, forming the active community of states for nearly three centuries. These new states not only have completely different religious, social, and cultural backgrounds, their own sets of cultural and legal values, but a large majority of them are extremely least-developing and developing. The needs and aspirations of these, what Courteously called the "developing" states of the Third World, are bound to be different from those of the western technologically advanced states of Europe and North America” [6].

New countries which are generally poor and developing, have succeeded in influencing international law to give special consideration to the conditions of least-developing and developing countries. Among these can be seen in the regulation of exploitation of natural resources in EEZ. As for remote sensing, consideration of the needs of developing countries has also been stressed by the 1986 Principles of Remote Sensing, namely that developing countries have the opportunity to play a role in remote sensing activities concerning their territories.

\section{The Right of the Sensed States to the Data}

Principle XII of the Remote Sensing Principles constitute the right access of the sensed states to the data concerning their territory, including primary and processing data. This data shall be provided for the sensed states in the light of non-discrimination and a reasonable cost term. This principle was accepted as a return for the acceptance of the freedom of carrying out remote sensing activities during the process of negotiation of the Remote Sensing Principles. Therefore, as noted by Sergio Marchisio, the freedom and the access data have been inseparably linked in the 1986 package deal, and, as such, bear an inextinguishable value [7]. However, it is important to note that this principle does not entitle an obligation for a sensing state to provide the data for free. It also does not forbid the commercialization of the data. The data from remote sensing may provide for the market offer.

Practices in the market of the data showed that this field will be mainly driven by market consideration. Commercial operators adopted a policy that does not give priority or any preferential right to the sensed state. The data available for all customers with the basis of the ability to pay the cost. This may bring issue for the developing states since the price might be high and they cannot afford the price [8].

However, this practice shall be guided by the term of reasonable cost and the special needs and situations of developing countries. Therefore, the cost of the data shall be affordable that can guarantee the developing sensed states to access the data. Referring to Ram Jakhu opinion that a fair balance of interests of the sensing and sensed States, and be conducive to the interests of the private sector involved in the commercialization of remote sensing products and service and thus expanding their benefits to all shall be stressed in a new promulgation of international convention concerning remote sensing (Jakhu 2006, 101).

\section{Indonesian's National Space Legislation}

Indonesia promulgated outer space activities in Act Number 21 Year 2013 Concerning Outer space. Remote sensing activities arrange further in the Government Regulation Number 11 Year 2018 Concerning Remote Sensing. Act of Republic of Indonesia Concerning Remote sensing defined remote sensing as activities comprises: collecting data, processing data, storage, and distribution data, usage of data and information dissemination. Those activities produce primary data, processing data, and analysis information. Remote sensing data may obtain from satellite operation, earth station operation, and satellite imagery. However not all of the data from satellite operation, earth station, and satellite imagery may provide by Lembaga alone. Therefore, The Lembaga may make operation cooperation with foreign providers in operating satellite stations and earth stations. Despite satellite imagery may acquire from the commercial provider and non-commercial provider.

The rules regarding remote sensing both in Law Number 21 Year 2013 concerning Space and Government Regulation Number 11 Year 2018 concerning Remote Sensing regulate more technical matters. The fundamental issues relating to remote sensing, such as data access and international cooperation in remote sensing, has not been explicitly regulated. Concerning these two fundamentals, it is necessary to have a clearer arrangement based on the legal concept of 
Data Access for Countries that are sensed with a special consideration for least-developing and developing countries.

The legal concept of Data Access for countries that are sensed with a special consideration for developing countries means that the countries that are sensed must have access to remote sensing data regarding their territory and that there is a special consideration for least-developing and developing countries regarding the data acquisition. These special considerations are mainly concerned with the price or cost requirements for data acquisition.

This legal concept can be the basis for Indonesia in the formulation of remote sensing rules and policies. This is because Law Number 21 Year 2013 concerning Space and Government Regulation Number 11 Year 2018 does not regulate Indonesia's data access to data concerning territories that are sensed by other countries. Law Number 21 Year 2013 also does not emphasize special considerations for the situation of poor and developing countries. Emphasis is precisely given to the principle of freedom of exploration and exploitation and not ownership of space, as affirmed in Article 3 of Law Number 21 Year 2013 concerning Space.

From the aspect of state practice or usus, enumerated the importance of consideration of the needs and special interests of developing countries can be seen as a part of the process of establishing customary international law. This has been affirmed by Loh Ing Hoe.et.al who illustrates the principle of remote sensing - that recognition of the needs and interests of developing countries - can someday harden into custom. This recognition also becomes important to anticipate the loss of special and different treatment for developing countries as predicted by B.S Chimni as follows:

"...there is the refusal to affirmatively differentiate between States at different stages of the development process. International law today articulates rules that seek to transcend the phenomena of uneven global development and evolve uniform global standards to facilitate the mobility and operation of transnational capital. There is no longer space for recognizing the concerns of States and peoples subjected to long colonial rule. Develop and developing states are to be treated alike in the new century and the principle of special and differential treatment is to be slowly but surely discarded. Equality rather than difference is the prescribed norm."

The establishment of international customary law regarding remote sensing, especially concerning the interests of poor and developing countries is the preferable way to fill the lacuna of international law regarding remote sensing. Therefore, constant and uniform practice among countries is needed for the formation of norms of customary international law.

In order to develop uniformity among the leastdeveloping and developing countries, there is a need for cooperation between countries. Yun Zhao mentioned that international cooperation is the possible solution to be carried out among developing countries. This should be one of the things taken into consideration for legislators in developing countries in the preparation of space legislation. Formulation of a legal framework regarding space cooperation that is efficient, feasible and can be implemented is part of the legal policies that must be developed by developing countries [2]. In line with Yun Zhao's opinion, Loh Ing Hoe et al. mentioned the need to build cooperation between countries in the form of regional agreements that emphasize protection for the territorial sovereignty of the countries concerned [4].

\section{CONCLUSION}

Indonesian Outer Space law, particularly in part of remote sensing, does not represent the fundamental rules concerning the need of middle space power. Vulnerable position as a middle space power shall be the main consideration in building the rules of remote sensing. Therefore, the legal concept of "The Access Data with special Consideration for Poor and Developing Countries" shall be the foundation for developing the rules concerning remote sensing activities. With this legal concept Indonesia may enact rules that give Indonesia government authority for asking special consideration in accessing data from remote sensing activities. However, this concept can have an enforcement power only if it hardens into customary rules. For achieving the customary rules Indonesia and other poor and developing countries shall make cooperation through multilateral convention or regional convention.

\section{REFERENCES}

[1] D. Golston and B. Basely-Walker, "The Realities of Middle Power Space Reliance," 2015

C. L. Borgman, "OPEN DATA, GREY DATA, AND STEWARDSHIP: UNIVERSITIES AT THE PRIVACY FRONTIER," HeinOnline, 2018, doi: 10.15779/Z38B56D489.

[3] S. P. Krafft, "Boston College International and Comparative Law Review In Search of a Legal Framework for the Remote Sensing of the Earth from Outer Space RECENT DEVELOPMENT In Search of A Legal Framework for the Remote Sensing of the Earth from Outer Space," 1981. Accessed: Jul. 13, 2020. [Online]. Available: http://lawdigitalcommons.bc.edu/iclr/vol4/iss2/6.

[4] L. Hoe, R. Umar, M. K.-I. J. of, and undefined 2017, "Evaluation of Remote Sensing Principles 1986: The Unsolved Problems," ideas.repec.org, Accessed: Jul. 13, 2020. [Online]. Available: https://ideas.repec.org/a/hur/ijarbs/v7y2017i7p475-490.html.

Y. Z.-P. of the S. L. Conference and undefined 2006, "National space legislation with reference to China's practice.'

R. Anand, "Confrontation Or Cooperation?: International Law and the Developing Countries," 1987.

M. Ram, S. Jakhu \& Sergio, "Comment on the Discussion Paper on Asia's Role In Remote Sensing And Legal Aspect of Acces To High Resolution Satellite Imagery Presented By Mr.K.Sridhara Murthi," in Proceedings of The Space Law Conference 2006, Asian Cooperation in Space Activities A Common Approach to Legal Matters, 2006.

[8] K. Sridhara, "Asia's Role In Remote Sensing And Legal Aspect of Acces To High Resolution Sattelite Imagery," in Proceedings of The Space Law Conference 2006, Asian Cooperation in Space Activities A Common Approach to Legal Matters, 2006. 